DEC

BUILDING SCIENCE SERIES 24

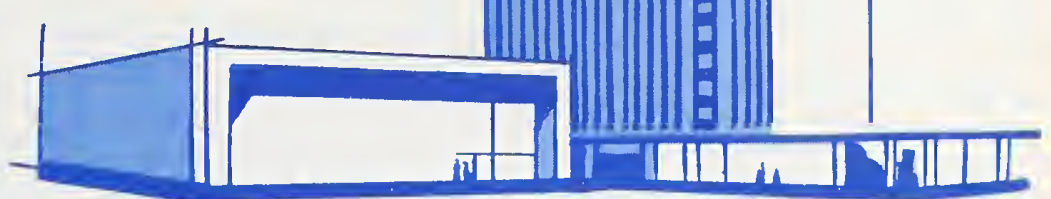

Natural Weathering of

Mineral Stabilized Asphalt Coatings

On Organic Felt 


\section{Contents}

1. Introduction

1.1. Scope of study _... 1

2. Experimental details__._.

2.1. Types of specimens _... 1

2.2. Equipment for preparation of specimens_______._._. 2

a. Smooth-surface, felt-base specimens _............. 2

b. Granule-surfaced specimens........ 2

c. Back-coater .

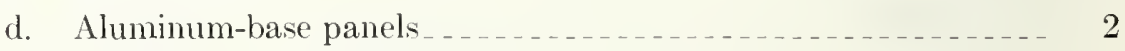

2.3. Materials__._. 2

a. Mineral matter

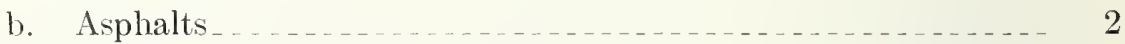

c. Saturated felts . .

d. Aluminum panels

e. Granules _....... 4

2.4. Specimen preparation

a. Smooth-surface, felt-base specimens_______ 4

b. Granule-surfaced, felt-base specimens _._.

c. Smooth-surface, aluninum-base specimens _._._._. 4

2.5. Specimen exposure _._. 4

a. Felt-base specimens

b. Aluminum-base specimens _._._.

2.6. Specimen evaluation _._.

a. Felt-base specimens .

b. Aluminum-base specimens _._. 4

3. Progress of deterioration

3.1. Smooth-surface specimens _

3.2. Granule-surfaced specimens _

3.3. Blistering .

t. Failure criteria

5. Outdoor performance

5.1. Smooth-surface, felt-base specimens _._. 7

5.2. Granule-surfaced, felt-base specimens _ _ _ 10

(i. Correlation with exposures in accelerated weathering machine _._. _ _ 10

7. Conclusions _

8. References 


\title{
Natural Weathering of Mineral Stabilized Asphalt Coatings on Organic Felt
}

\author{
Sidney H. Greenfeld
}

\begin{abstract}
Sixteen years of outdoor weathering of laboratory-prepared smooth-surface and mineralsurfaced, felt-base roofing specimens has provided information on the effects of mineral additives on the durability of coating-grade roofing asphalts. Six finely divided mineral additives (blue black slate, clay, dolomite, fly ash, mica, and silica) were evgluated at concentrations up to 60 percent in California, Mid Continent and Venezuela asphalts. The mineral-surfaced specimens are all performing satisfactorily, and show only minor degrees of degradation. () the smoothsurfaced specimens, the Mid-Continent asphalt performed the best and the California asphalt the poorest. The mica and blue black slate increased the durabilities of all three asphalts at all concentrations and two coating thicknesses. Fly ash, clay, dolomite, and silica were beneficial in some combinations, but had little effect in others. In gencral, these early results from outdoor exposure tend to corroborate the results obtained on these coatings cxposed in weatherometers.
\end{abstract}

Key words: Additive; asphalt; durability; felt; stabilizer; weathering.

\section{Introduction}

The most certain $"$ ay to determine how a product will weather in a given geographical area is to expose the product and observe it over the years. For materials or systems of low life expectancy, this procedure has been proven extremely satisfactory. For building materials, where the life expectancy is of the order of decades, the observed frequently outlives the observers. Those who design the tests, know their background and appreciate the significance of results, pass out of the picture and are replaced by others who find current work of greater interest. In many instances, the current production is no longer strictly comparable to that being observed.

Therefore, it has long been the practice to design rapid methods for evaluating materials and simultaneously exposing the same materials to the weather. The results of the laboratory evaluation become available in a relatively short period of time; those of the simulated-service tests (outdoor exposures) get lost in the shuffle and the validity of the rapid tests is never proven.

This study was designed in 1947 by the Research
Committee of the Asphalt Roofing Manufacturers Association 1 to include a simulated-service study and several degrees of accelerated evaluation of the system: coating asphalt and mineral additives. The laboratory phase of the work was completed in 1954 and a series of reports and publications issued $[1,2,3]^{2}$. The verification of the conclusions drawn in these articles will be found in the results obtained for the outdoor tests. This paper is in the nature of a progress report of the first 15-17 years of these outdoor tests.

\subsection{Scope of Study}

The mineral additive-asphalt systems included in this study consisted of three asphalts and six mineral additives at three concentrations on one grade of shingle felt. The coatings were applied in two film thicknesses, and were exposed unsurfaced and surfaced with roofing granules.

\footnotetext{
1 Formerly the Asphalt Roofing lndustry Bureau.

2 Figures in brackets indicate the literature references at the end of thi; paper.
}

\section{Experimental Details}

\subsection{Types of Specimens}

Three types of specimens were included in this study. The basic specimen was a smooth-surface coated felt. These were exposed with coating thicknesses of 15 and 25 mils, ${ }^{3}$ were back-coated with the same coating blend, and were dusted with mica retained on a No. 100 sieve.
The first type of specimen was made on $9-\times 12$-in 4 felts and trimmed to $7 \times 11$ in prior to exposure to remove any edge effects.

The second type of specimen also had a felt base. In addition to being front and back coated, it was surfaced with granules. These, too, were trimmed to $7 \times 11 \mathrm{in}$. 
The third type of specimen was used for accelerated weathering tests. It consisted of the coating on $2^{3}$ - $-\times 6$-in aluminum panels. The results of these tests were reported earlier [3].

\subsection{Equipment for Preparation of Specimens}

\section{a. Smooth-Surface, Felt-Base Specimens}

Crimped (solder free) gallon cans.

Asphalt melting bath.

Six-ounce ladle.

Laboratory hydraulic press with $12-\times 14$-in cadmiun-plated platens.

Tempered hardboard, $12 \times 14$ in.

Kraft paper, $12 \times 14 \mathrm{in}$.

Cellophane, $12 \times 14$ in.

Dextrin-coated paper, $12 \times 14 \mathrm{in}$.

\section{b. Granule-Surfaced Specimens}

All of the granule-surfaced specimens were made on the apparatus shown in figure 1. Its principal parts are:

A. Hot plate for keeping the base warm during the pouring of the coating.

B. Variable-voltage-controlled, temperature-regulated doctor bar for spreading the coating and regulating its thickness.

C. Granule hopper and fluted granule spreader.

D. S-rolls for initial embedment of the granules and removal of excess.
E. Embedding rolls.

F. Belt drive for pulling canvas belt through the machine.

\section{c. Back-Coater}

The felt-base specimens were all back-coated with the apparatus shown schematically in figure 2 .

\section{d. Aluminum-Base Panels}

The equipment used in preparing the aluminum base specimens is described in ASTM D1669, Standard Method for Preparation of Test Panels for Accelerated and Outdoor Weathering of Bituminous Coatings [1] and in reference [3].

\subsection{Materials}

\section{a. Mineral Matter}

The six minerals used in this investigation were blue black slate, Florida clay, Niagara dolomite, low-carbon fly ash, Tennessee mica, and Lake Erie silica. The properties of these materials are listed in table 1.

\section{b. Asphalts}

The descriptions and properties of the three asphalts used in this investigation were reported previously [3] and are tabulated in table 2 .

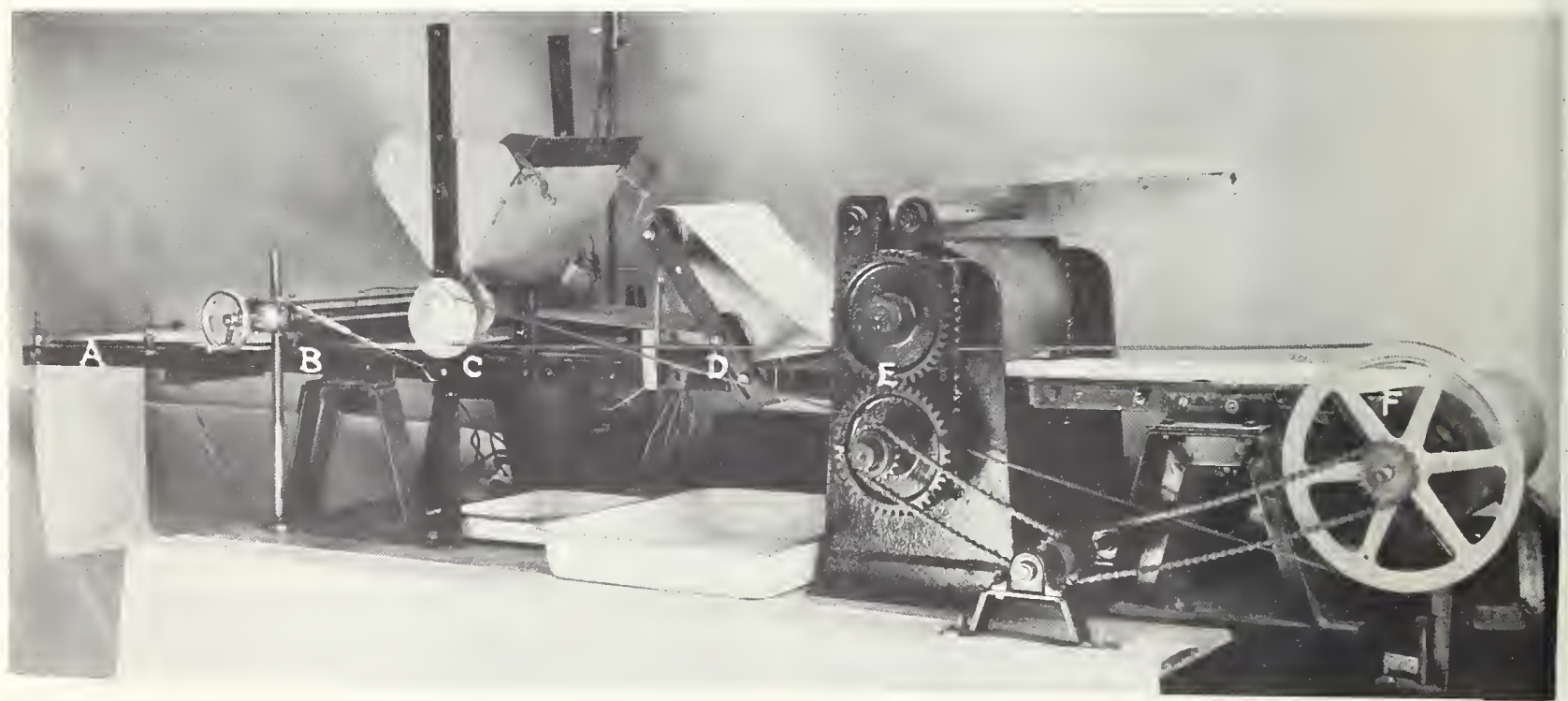

FIGURE 1. A pparatus for preparing granule-surfaced specimens.

A. Heated bed for keeping felts warm while asphalt coating is poured on them.

B. Doctor bar for leveling and defining coating thickness.

C. Granule hopper and distributor.

D. Granule placement S-rolls.

F. Granule pressing, or embedding, rolls. 


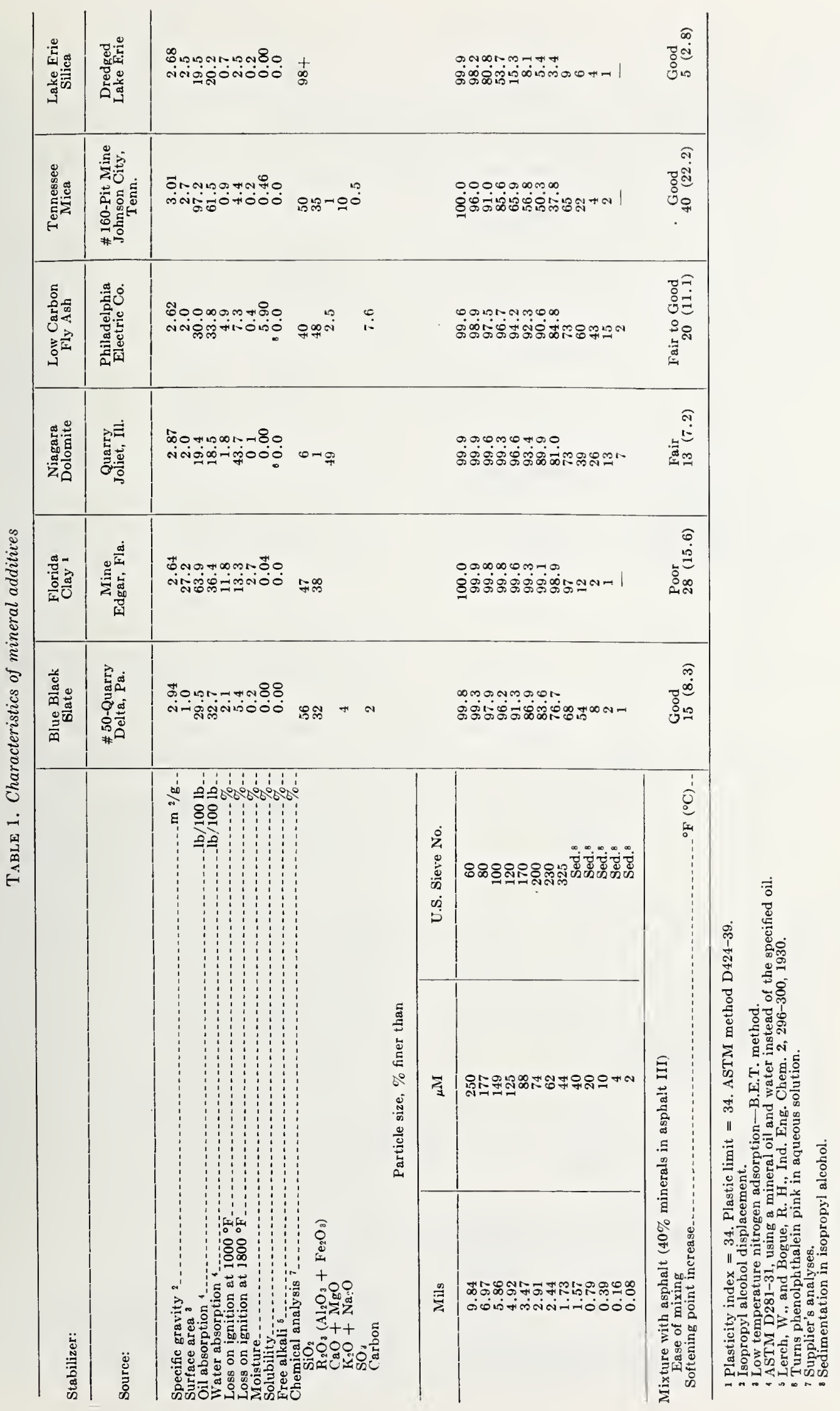




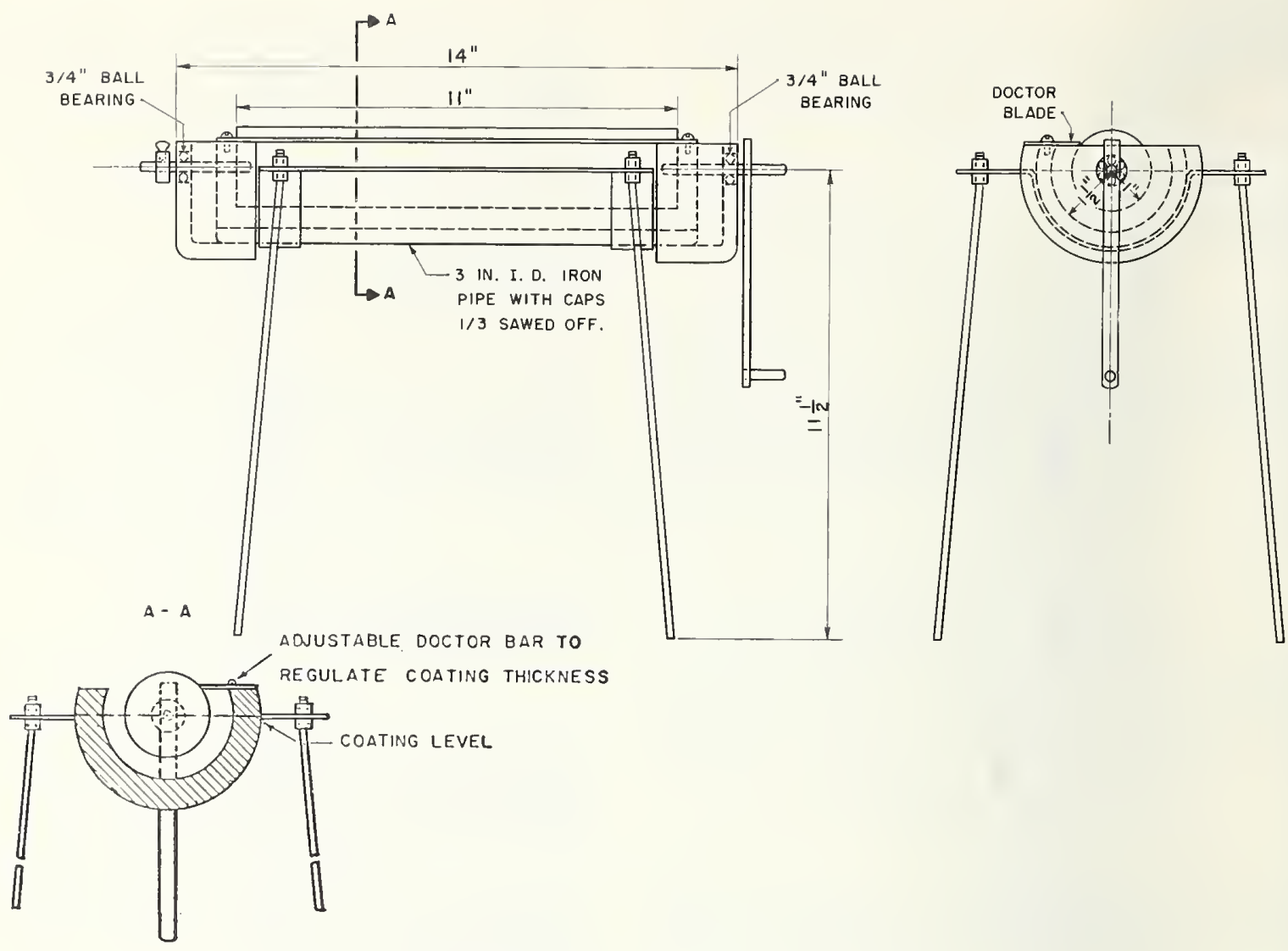

Figure 2. Apparatus for coating the backs of the specimens.

Each specimen was placed face up on the top of the 11 -incylinder and the crank turned to apply a thin coating on its back.

TABI- 2. Characteristics of unstabilized asphalt coatings used as controls

\begin{tabular}{|c|c|c|c|}
\hline Asphalt & California & Mid-continent & Venezuela \\
\hline Test & & & \\
\hline 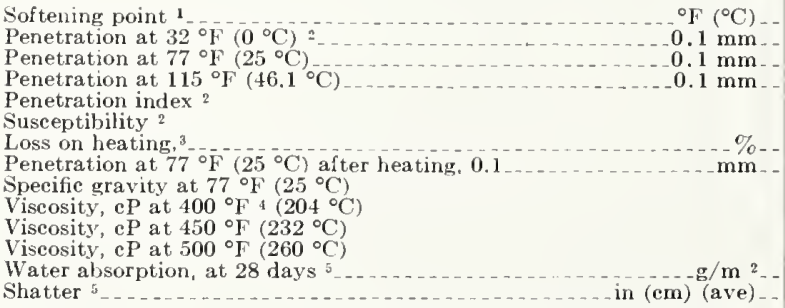 & $\begin{array}{l}223 \\
10 \\
17 \\
30 \\
4.7 \\
1.16 \\
0.22 \\
17 \\
1.015 \\
280 \\
100 \\
25 \\
7.2 \\
6.3(16.0)\end{array}$ & $\begin{array}{l}224(106.5) \\
11 \\
17 \\
26 \\
4.7 \\
0.87 \\
0.03 \\
17 \\
0.999 \\
420 \\
140 \\
53 \\
4.6 \\
8.3(21.1)\end{array}$ & $\begin{array}{l}227 \quad(107.8) \\
11 \\
14 \\
21 \\
4.5 \\
0.73 \\
0.10 \\
14 \\
1.018 \\
375 \\
130 \\
28 \\
3.7 \\
2.7 \quad(6.9)\end{array}$ \\
\hline
\end{tabular}

1 ASTM method D36-26

${ }^{2}$ ASTM method D5-52. P. I. from Nomograph, and $\mathrm{S}=\frac{\text { Pen. } 115^{\circ} \mathrm{F}\left(46.1^{\circ} \mathrm{C}\right)-\text { Pen. } 32^{\circ} \mathrm{F}\left(0^{\circ} \mathrm{C}\right)}{\text { Pen. } 77^{\circ} \mathrm{F}\left(25^{\circ} \mathrm{C}\right)}$

(6)

3 ASTM method D6-39T.

${ }^{4}$ Brookfield viscometer; $1 \mathrm{cP}=0.001 \frac{\mathrm{N} . \mathrm{s}}{\mathrm{m}^{2}}$.

5 Specimens, 3 -in diam $\times{ }^{3 / 6}$-in thick. submerged 1/1/in in distilled water at $77^{\circ} \mathrm{F}\left(25^{\circ} \mathrm{C}\right)$,

6. $L_{1 / 2}-1$ weight was dropped on a 3 -in diam specimen, 36 -in thick. in a mixed ice and water bath.

\section{c. Saturated Felts}

The dry felt was prepared for this project in rolls $12 \pm 1 / 2$ in wide by $300 \mathrm{ft}$ long and shipped by one of the sponsoring companies to another of the sponsors for saturation by personnel on the project. The dry and saturated felts had the characteristics listed in table 3 . 
TABLE 3. Characteristics of felt

\begin{tabular}{|c|c|c|c|c|}
\hline \multicolumn{5}{|c|}{ Dry felt } \\
\hline $\begin{array}{l}\text { Furnish, \%: } \\
\text { Gauge, lb/480 ft? } 2 \\
\text { Kerosene capacity } 1 \\
\text { Caliper, mils: } \\
\text { Tensile, ll /in } \\
\text { Asli, \%: }\end{array}$ & $\begin{array}{l}\begin{array}{l}\text { Rags } \\
\text { Paper } \\
\text { Asplund } \\
\text { Scrap felt }\end{array} \\
\\
\end{array}$ & $\mid$\begin{tabular}{c}
$\cdots \ldots$ \\
$\cdots$ \\
\hdashline
\end{tabular} & $\begin{array}{cr} \\
\cdots\end{array} \begin{array}{r}20 \\
45 \\
\hdashline\end{array}$ & $\begin{array}{c}53 \pm 2 \\
1.90 \pm 0.01 \\
57 \pm 3 \\
31 \\
6.8\end{array}$ \\
\hline \multicolumn{5}{|c|}{ Saturated felt } \\
\hline \multirow[b]{3}{*}{$\begin{array}{l}\text { California asphalt } \\
\text { Mid-Continent asphal } \\
\text { Venezuela asphalt. . }\end{array}$} & & & \multicolumn{2}{|c|}{ Saturation } \\
\hline & & & $\begin{array}{l}\text { Percent of } \\
\text { felt weight }\end{array}$ & $\begin{array}{l}\text { Percent of } \\
\text { kerosene } \\
\text { capacity }\end{array}$ \\
\hline & & & $\begin{array}{l}177 \\
183 \\
187\end{array}$ & $\begin{array}{l}93 \\
96 \\
98\end{array}$ \\
\hline
\end{tabular}

${ }^{1}$ Burette method ARIB No. 2.125, A pril 1954.

$21 \mathrm{lb}=0.45 \mathrm{~kg}$ (approx).

\section{d. Aluminum Panels}

The panels, made from $\mathrm{S}-2$ aluminum alloy, were 6 in long, $2 \frac{3}{4}$ in wide, and 0.065 in thick.

\section{e. Granules}

The granules were of the eeramie type, with the charaeteristics listed in table 4 . These eharacteristics were supplied by the granule manufaeturer and no attempt was made to verify them.

\subsection{Specimen Preparation}

\section{a. Smooth-Surface, Felt-Base Specimens}

The asphalts were melted in a double-boiler, eonsisting of a one-gallon can, wrapped in aluminum foil to prevent eontamination, sitting in a twogallon bucket half full of asphalt. The temperatures of both the asphalt under investigation and the asphalt in the bath were watched eonstantly to prevent any overheating. When the temperature of the test asphalt was in the range of 400 to $450{ }^{\circ} \mathrm{F}$ $\left(204\right.$ to $232{ }^{\circ} \mathrm{C}$ ), any required mineral matter, preheated to $300^{\circ} \mathbf{F}\left(149^{\circ} \mathrm{C}\right)$, was stirred into it with a large chromium-plated ladle. The mixture was continually stirred at $450^{\circ} \mathrm{F}\left(232^{\circ} \mathrm{C}\right)$ until it no longer frothed. All compositions were made and are reported on a weight-percent basis.

The saturated felts, cut into $9-\times 12$-in sheets, were heated in an air oven at $300{ }^{\circ} \mathrm{F}\left(149{ }^{\circ} \mathrm{C}\right)$ to warm them and to eliminate moisture. They were ready for use when the saturant, which came to the surface as the felts were heated, was eompletely reabsorbed.

When the felts and coating were in working condition, a felt was removed from the oven and placed on a sheet of cellophane backed by a double thickness of 12- $\times 14$-in Kraft paper and a 12- $\times 14$-in piece of tempered hardboard. Approximately one and a half times the required quantity of coating was distributed over the felt and spacers of the required thickness (felt thickness plus :3 mils) were plaeed along two of the sides of the felt. A sheet of dextrin-coated papel, two sheets of Kraft paper and a piece of tempered hardboard were successively placed over the coating, and the assembly was put into the hydraulic press. The press was closed and the pressure raised to about 120 psig. After about $30 \mathrm{~s}$, the panel was removed from between the sheets of Kraft paper and placed in a water bath at room temperature, where the cellophane and dextrin paper soon floated free. The panel was thoroughly washed and dried and its thickness measured.

When the required number of aeceptable panels had been prepared, the hot coating was ladled from the melting bath to the baek-coater, which had previously been heated to about $450{ }^{\circ} \mathrm{F}\left(232{ }^{\circ} \mathrm{C}\right)$. While one man rotated the roller slowly, another passed the back of the panel over the roller, picking up a thin eoating. The back eoating was dusted with nica while still warm. Upon cooling, eaeh specimen was cut to $7 \times 11$ in and exposed the next day on wooden roof decks, which had been covered with smooth-surface roll roofing (faeing due south and at an angle of $45^{\circ}$ ). An area of $4 \times 7$ in was exposed, leaving each specimen a 3-in head lap.

TABLE 4. Characteristics of granules

Base Rock: $-10+35$ mesh Wausau, Wisconsin graystone (Argillite).

Chemical Analysis

\begin{tabular}{|c|c|c|}
\hline & Component & Pereentage \\
\hline & $\begin{array}{l}\mathrm{SiO}_{2} \\
\mathrm{Al}_{2} \mathrm{O}_{3} \\
\mathrm{Fe}_{2} \mathrm{O}_{3} \\
\mathrm{MgO} \\
\mathrm{CaO} \\
\mathrm{Na}_{2} \mathrm{O} \\
\mathrm{CO}_{2} \\
\mathrm{H}_{2} \mathrm{O} \text { (at } 105^{\circ} \mathrm{C} \text { ) }\end{array}$ & $\begin{array}{l}70.0 \\
17.4 \\
5.7 \\
1.5 \\
0.3 \\
4.8 \\
0.6 \\
0.04\end{array}$ \\
\hline Pigments: & \multicolumn{2}{|c|}{$\begin{array}{l}\text { Chromium oxide and phthalocyanine green, bonded } \\
\text { with sodium silicate. }{ }^{1}\end{array}$} \\
\hline $\begin{array}{l}\text { Aranules: } \\
\text { Coldity: } \\
\text { Color fixation: } \\
\text { Wettability: } \\
\text { Oil absorption: }\end{array}$ & \multicolumn{2}{|c|}{$\begin{array}{l}\text { Extract from } 25 \mathrm{~g} \text { is equivalent to } 0.1 \mathrm{ml} \text { of } 0.1 N \text { acid. } \\
30 \text { percent pigment loss. } \\
80 \text { percent. } \\
6 \mathrm{lb} / \text { ton }^{2}(3 \mathrm{~g} / \mathrm{kg}) \text {. }\end{array}$} \\
\hline
\end{tabular}

Particle Size (Tyler)

\begin{tabular}{r|r} 
Sieve No. & Percent \\
\hline Retained on 10 & 0.7 \\
Retrined on 14 & 33.9 \\
Retained on 20 & 36.0 \\
Retained on 28 & 21.6 \\
Retained on 35 & 7.2 \\
Passing 35 & 0.5
\end{tabular}

Granules were oiled with $5 \mathrm{lb}$ per ton $(2.5 \mathrm{~g} / \mathrm{kg})$ of lightweight parafin oil, complying with the following specification:

Sp. Gr.

Viscosity at $100^{\circ} \mathrm{F}\left(37.8^{\circ} \mathrm{C}\right)$

Flash point (COC)

Fire point (COC)

Fire point
Pour point $26-30^{\circ} \mathrm{API}$ 96-105 S.U.S $350^{\circ} \mathrm{F}\left(177^{\circ} \mathrm{C}\right) \mathrm{min}$ $95{ }^{\circ} \mathrm{F}\left(202^{\circ} \mathrm{C}\right) \mathrm{min}$. $25^{\circ} \mathrm{F}\left(-3.9^{\circ} \mathrm{C}\right) \max$.

1 U.S. Patent No. $2,417,058$.

2 Basis of test not reported. 


\section{b. Granule-Surfaced, Felt-Base Specimens}

The asphalt and felts were prepared as in 2.4a. The hot plate (A) on the laboratory roofing machine (fig. 1) was heated to about $250^{\circ} \mathrm{F}\left(121^{\circ} \mathrm{C}\right)$ and the doctor bar (B) to $450{ }^{\circ} \mathrm{F}\left(232{ }^{\circ} \mathrm{C}\right)$. The canvas belt was threaded through the machine and a sheet of 12-in wide Kraft paper three feet long was fastened to its end, about 4 in in front of the doctor bar. In order to be assured that the doctor bar was at the proper distance from the machine bed, a blank run was made in which no granules were used. When cool, the thickness of the coated panel was measured.

In a normal run the felt panel was fastened with masking tape to the Kraft paper on the hot plate. About one and a half times the required coating was distributed over the panel. The motor was started and the panel was pulled under the doctor bar (B) and granule hopper (C); then the motor was stopped for 2 min to permit the panel to cool and the granules to become firmly set. Then the panel was drawn through the S rolls (D) and embedding rolls $(\mathrm{E})$. The panel was removed from the belt and passed backwards through the embedding rolls again. Because of the heavy gear on one side of the embedding rolls and because the rolls were not crowned, this procedure was necessary to make the embedment of the granules more uniform. The panels were backcoated as in $2.4 \mathrm{a}$.

\section{c. Smooth-Surface, Aluminum-Base Specimens}

The smooth-surface, aluminum-base specimens were prepared as in ASTM D 1669, which is based on work reported in reference [3].

\subsection{Specimen Exposure}

a. Felt-Base Specimens

Within $24 \mathrm{hr}$ after their preparation the felt-base specimens, both smooth and granule surfaced, were exposed outdoors on the roof of the Industrial Building at the former NBS Washington site, facing due south and at an angle of 45 deg. The
7- $\times 11$-in specimens were mounted by nailing shingle fashion on protected decks with $4-\times 7$-in tabs exposed to the weather. The decks for the smooth-surface specimens were protected with 55-lb roll roofing, which also served as the under-layment for these specimens; the granule-surfaced specimens had a 90-lb mineral-surfaced roll roofing as underlayment and deck cover.

\section{b. Aluminum-Base Specimens}

The aluminum-base specimens were exposed in two weatherometers to cycle 51-9C of ASTM D 529, within $24 \mathrm{hr}$ of the time they were prepared. A detailed account of the apparatus and procedure is given in reference [3].

\subsection{Specimen Evaluation}

\section{a. Felt-Base Specimens}

The $4-\times 7$-in exposed portions of the specimens were examined through a transparent grid with 98 squares $[0.40 \times 0.40 \mathrm{in}]$ covering the central $31 / 4^{-}$ $\times 61 / 4$-in area. The areas around the edges $[0.325$ in wide] of the $4-\times 7$-in area were excluded from the examination to eliminate the edge effects. The numbers of squares with cracks and spalled coating were counted and recorded during each inspection. Inspections were made every three months during the first two years of exposure and semiannually thereafter. The semiannual inspections were made in March and September.

\section{b. Aluminum-Base Specimens}

The aluminum-base specimens were examined with a high voltage probe in accordance with ASTM D 1670. Spark photographs were taken of all specimens with three or more breaks in the coating. These photographs were examined through a transparent 60- rectangle grid covering the central $2-\times 5$-in portion of the specimen. Only failures by cracking were rrcorded for this type of specimens.

\section{Progress of Deterioration}

\subsection{Smooth-Surface Specimens}

When the smooth-surface specimens were first prepared, they had a matte finish corresponding to the texture of the dextrin-coated release paper used on them. After short periods of exposure, the surfaces became glossy. Continued exposure produced elevated ridges, followed by thinner connecting ridges. These ridges were the result of expansion of the surface as it became oxidized. As oxidation progressed; the surface became progressively more water soluble; material was dissolved by rain outdoors or water spray in the weatherometers, and the glossy, ridged surface assumed a matte appearance. With time, widely spaced cracks appeared. These cracks usually penetrated the felt-base specimens fairly rapidly through the coating to the felts. In the aluminum-base specimens, the cracks frequently remained on the surface for relatively long periods of time and failure was evidenced by pinholing in noncracked areas or at crack intersections.

In the felt-base specimens, widely spaced cracks became interlaced with narrower cracks until spalling of the small areas surrounded by cracks began. As coating spalled from the specimens, the substrates were exposed to the weather. In the aluminum-base specimens, exposure was usually discontinued prior to the spalling phase of weathering. In the felt-base specimens, the spalling permitted the saturated felt to be degraded rapidly by the weather. Photo- 
oxidation rapidly destroyed the saturant and permitted water to enter the felts and, through alternate wetting and drying, shrink and distort them. Finally, the weakencd tabs were blown away.

\subsection{Granule-Surfaced Specimens}

The granule-surfaeed speeimens have shown only the early stages of detcrioration during the 15 ycars they have been exposed to the weather. Changes observed early in the exposure period eonsisted of small losses of granules in most of the speeimens and heavier losses of granules in the few specimens in which poor granule adhesion was measured prior to exposure. After about 12 years of cxposurc, eracks began to appear in the eoatings. About a quarter of the speeimens had cracks in 5 pereent of their surfaee areas (five grid areas) after 12 and a half years. No spalling of the eoatings has been observed in any of these speeimens since their exposure in 1952. However, in the normal course of events, as wcathering progresses, generally more granules will be lost, more cracking will oceur and, finally, the coatings will spall off the saturated felts, just as in the smoothsurfaee, felt-base speeimcns. The granules protect the coating from solar radiation and greatly delay the later stages of detcrioration.

\subsection{Blistering}

Early in the exposure of the smooth-surface, feltbase specimens some small blisters were obscrved. These were prineipally around the elges, but in some of the specimens made with Mid-Continent and Venezuela asphalt, blisters appeared well within the areas inspected. Only a very few specimens made with California asphalt had any blisters; none had more than threc. While blistering contributes to poor appearance, it does not interfere with the cssential funetion of roofing, whieh is to keep the structures weatherproof. Therefore, blistering is not normally eonsidered as a critcrion of failure. However, blisters can aet as eenters of stress eonccntration and lead to earlier cracking and spalling of the coating. Thus, the effect of blistcring is manifested in the reported craeking and spalling. The only other comment that can be madc eonecrning blistering is that the largest ineidence of blistcring was associated with the eoatings made from the more durable asphalts.

The aluminum-base specimens and the granulesurfaced, felt-base specimens expcrienced cssentially no blistering.

\section{Failure Criteria}

When a product exposed to the weather no longer performs the function for which it was designed, it has failed. However, it has become eustomary to replaee roofing for reasons other than, and earlier than, eomplete failures. Quite frequently, shingles are replaeed beeause they no longer have an aeeeptable appearance; on other oecasions failure can be anticipated in the near, but indefinite, future. Consequently, eertain standards of failure were arbitrarily seleeted by the sponsors of this program.

These failure eriteria appear in table 5 .
T.IBLe 5. Failure criteria

\begin{tabular}{|c|c|}
\hline Specimen type & Criterion of failure \\
\hline Smooth-surface, felt base & Spalls in 25 grid areas $(25 \%)$ \\
\hline Granule-surfaced, felt-base & $\begin{array}{l}50 \% \text { Granule loss in } 49 \text { grid } \\
\text { areas }(50 \%) \text { or spalls in } 25 \\
\text { grid areas }(25 \%) \text {. }\end{array}$ \\
\hline Aluminum-base & Cracks in 30 grid areas $(50 \%)$ \\
\hline
\end{tabular}

\section{Outdoor Performance}

\subsection{Smooth-Surface, Felt-Base Specimens}

The results of 200 months (162/3 years) of exposure of the smooth-surfaee, felt-base specimens to the weather are summarized in tables 6 and 7 . Information on erack devclopment is presented along with the observations of spalling. The ratio of the time in whieh an asphalt eoating w ith mineral matter in it reaehes a given level of deterioration to the time in whieh the same asphalt alone reaehes that same level of deterioration is also reported. This ratio is frequently more significant than the actual number of months of exposure, for this comparison of a eoating with mineral additives to its base asphalt tends to eompensate for variations in the weather, or climate. This technique was used in referenee [3], where the results of the accelerated weathering on these coatings were diseussed. (A few of the coatings 15 mils thick (table 6) and many more of those 25 mils thick (table 7 ) had not reaehed some of the levels of deterioration reported. This condition is indicated by dashes in both tables).

At every level of pcrformanee and in both thicknesses the Mid-Continent asphalt outperformed the Venezuela asphalt, whieh, in turn, outperformed the California asphalt. The mica-stabilized coatings out performed all the others; only one eoating had deteriorated to any of the seleeted levels in tables 6 and 7 in 200 months. The 15-mil California eoating with 35 pereent mica exhibited its first spalled areas in 164 months.

Before diseussing speeific pcrformanees, however, a word of explanation is in order concerning the mechanism of cracking and why craeking, trough ultimately contributing signifieantly to shingle 
TABLE 6. Smooth surface specimens ${ }^{1}$

15 Mil $(0.38 \mathrm{~mm})$ Thickness

\begin{tabular}{|c|c|c|c|c|c|c|c|c|c|c|}
\hline \multirow{2}{*}{ Coating description } & \multicolumn{2}{|c|}{$25 \%$ Cracked } & \multicolumn{2}{|c|}{$50 \%$ Cracked } & \multicolumn{2}{|c|}{ Initial Spall } & \multicolumn{2}{|c|}{$25 \%$ spalled } & \multicolumn{2}{|c|}{$50 \%$ Spalled } \\
\hline & Months & Ratio & Months & Ratio & Months & Ratio & Months & Ratio & Months & Ratio \\
\hline 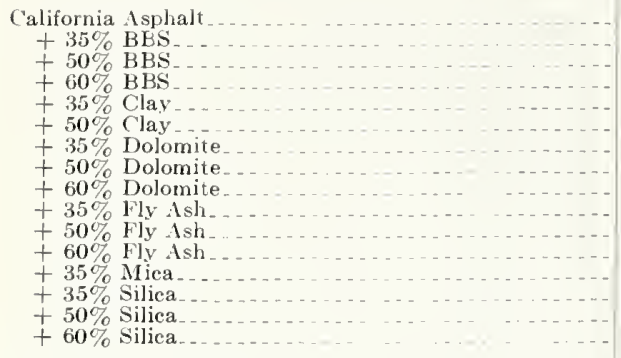 & $\begin{array}{r}15 \\
18 \\
38 \\
99 \\
19 \\
9 \\
18 \\
24 \\
24 \\
9 \\
9 \\
28 \\
23 \\
19 \\
18\end{array}$ & $\begin{array}{l}1.0 \\
1.2 \\
2.5 \\
6.6 \\
1.3 \\
0.6 \\
1.2 \\
1.6 \\
1.6 \\
0.6 \\
0.6 \\
1.9 \\
1.5 \\
1.3 \\
3.2\end{array}$ & $\begin{array}{r}15 \\
18 \\
40 \\
140 \\
19 \\
9 \\
18 \\
24 \\
24 \\
9 \\
9 \\
28 \\
23 \\
19 \\
48\end{array}$ & $\begin{array}{l}1.0 \\
1.2 \\
2.7 \\
9.3 \\
1.3 \\
0.6 \\
1.2 \\
1.6 \\
1.6 \\
0.6 \\
0.6 \\
1.9 \\
1.5 \\
1.3 \\
3.2\end{array}$ & $\begin{array}{r}35 \\
71 \\
101 \\
174 \\
42 \\
42 \\
37 \\
37 \\
40 \\
49 \\
52 \\
100 \\
164 \\
48 \\
54 \\
72\end{array}$ & $\begin{array}{l}1.0 \\
2.0 \\
2.9 \\
5.0 \\
1.2 \\
1.2 \\
1.1 \\
1.1 \\
1.1 \\
1.4 \\
1.5 \\
2.9 \\
4.7 \\
1.4 \\
1.5 \\
2.1\end{array}$ & $\begin{array}{r}19 \\
104 \\
139 \\
\overline{60} \\
79 \\
55 \\
55 \\
61 \\
65 \\
85 \\
133 \\
63 \\
72 \\
90\end{array}$ & $\begin{array}{l}1.0 \\
2.1 \\
2.8 \\
1.2 \\
1.6 \\
1.1 \\
1.1 \\
1.2 \\
1.3 \\
1.7 \\
2.7 \\
1.3 \\
1.5 \\
1.8\end{array}$ & $\begin{array}{r}55 \\
116 \\
145 \\
66 \\
91 \\
61 \\
58 \\
69 \\
77 \\
93 \\
139 \\
\overline{79} \\
78 \\
102\end{array}$ & $\begin{array}{l}1.0 \\
2.1 \\
2.6 \\
1.2 \\
1.7 \\
1.1 \\
1.1 \\
1.3 \\
1.4 \\
1.7 \\
2.5 \\
1.4 \\
1.4 \\
1.9\end{array}$ \\
\hline 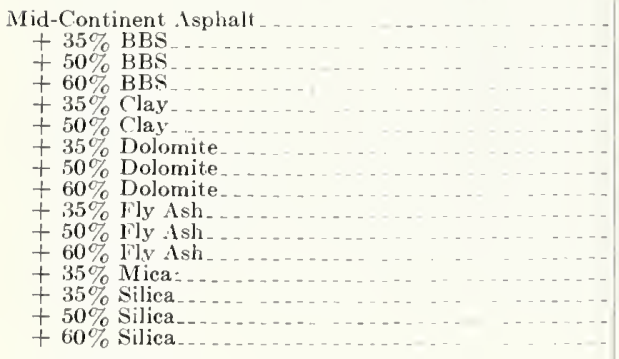 & $\begin{array}{r}32 \\
94 \\
71 \\
201 \\
29 \\
26 \\
53 \\
56 \\
62 \\
38 \\
36 \\
62 \\
31 \\
31 \\
34\end{array}$ & $\begin{array}{r}1.0 \\
2.9 \\
2.2 \\
0.3 \\
0.9 \\
0.8 \\
1.7 \\
1.8 \\
1.9 \\
1.2 \\
1.1 \\
1.9 \\
1.0 \\
1.0 \\
1.1\end{array}$ & $\begin{array}{r}32 \\
109 \\
100 \\
32 \\
29 \\
56 \\
59 \\
68 \\
38 \\
44 \\
100 \\
-38 \\
34 \\
37\end{array}$ & $\begin{array}{l}1.0 \\
3.4 \\
3.1 \\
1.0 \\
0.9 \\
1.8 \\
1.8 \\
2.1 \\
1.2 \\
1.4 \\
3.1 \\
1.2 \\
1.1 \\
1.2\end{array}$ & $\begin{array}{r}82 \\
118 \\
142 \\
79 \\
792 \\
88 \\
144 \\
105 \\
113 \\
88 \\
96 \\
41 \\
43 \\
80\end{array}$ & $\begin{array}{l}1.0 \\
1.4 \\
1.7 \\
1.0 \\
0.9 \\
1.1 \\
1.8 \\
1.3 \\
1.4 \\
1.1 \\
1.2 \\
-\overline{0.5} \\
1.1 \\
1.0\end{array}$ & $\begin{array}{r}120 \\
155 \\
102 \\
98 \\
130 \\
152 \\
157 \\
140 \\
143 \\
- \\
148 \\
158 \\
161\end{array}$ & $\begin{array}{l}1.0 \\
\frac{1.3}{-} \\
0.9 \\
0.8 \\
1.1 \\
1.3 \\
1.3 \\
1.2 \\
1.2 \\
- \\
1.2 \\
1.3 \\
1.3\end{array}$ & $\begin{array}{c}130 \\
\overline{176} \\
- \\
113 \\
107 \\
139 \\
159 \\
166 \\
T \\
148 \\
- \\
54 \\
173 \\
181\end{array}$ & $\begin{array}{r}1.0 \\
1.4 \\
0.9 \\
0.8 \\
1.1 \\
1.2 \\
1.3 \\
\mathrm{~T} \quad 1.1 \\
-\overline{1.2} \\
1.3 \\
1.4\end{array}$ \\
\hline 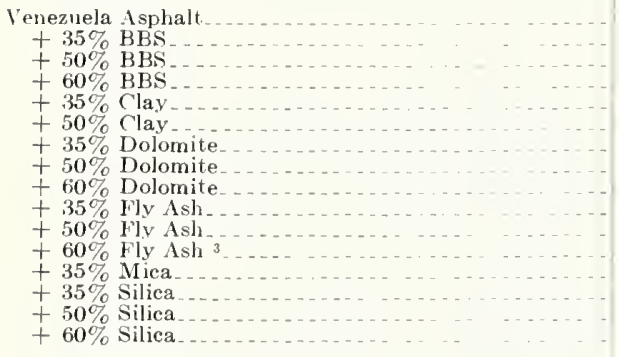 & $\begin{array}{l}27 \\
36 \\
54 \\
60 \\
17 \\
17 \\
21 \\
23 \\
29 \\
20 \\
27 \\
-19 \\
16 \\
19\end{array}$ & $\begin{array}{l}1.0 \\
1.3 \\
2.0 \\
2.2 \\
0.6 \\
0.6 \\
0.8 \\
0.9 \\
1.1 \\
0.7 \\
1.0 \\
\\
0.6 \\
0.6 \\
0.7\end{array}$ & $\begin{array}{l}27 \\
36 \\
57 \\
73 \\
17 \\
17 \\
21 \\
23 \\
30 \\
20 \\
27 \\
-16 \\
16 \\
19\end{array}$ & $\begin{array}{l}1.0 \\
1.3 \\
2.1 \\
2.7 \\
0.6 \\
0.6 \\
0.8 \\
0.9 \\
1.1 \\
0.7 \\
1.0 \\
\\
0.6 \\
0.6 \\
0.7\end{array}$ & $\begin{array}{r}5.5 \\
101 \\
9.5 \\
133 \\
54 \\
60 \\
66 \\
57 \\
63 \\
96 \\
66 \\
\\
51 \\
60 \\
53\end{array}$ & $\begin{array}{l}1.0 \\
1.8 \\
1.7 \\
2.4 \\
1.0 \\
1.1 \\
1.2 \\
1.0 \\
1.1 \\
1.7 \\
1.2 \\
0.9 \\
1.1 \\
1.0\end{array}$ & $\begin{array}{r}91 \\
156 \\
159 \\
84 \\
96 \\
101 \\
100 \\
114 \\
152 \\
152 \\
\\
79 \\
91 \\
99\end{array}$ & $\begin{array}{l}1.0 \\
1.7 \\
1.7 \\
0.9 \\
1.1 \\
1.1 \\
1.1 \\
1.3 \\
1.7 \\
1.7 \\
-\overline{0} \\
1.0 \\
1.1\end{array}$ & $\begin{array}{r}101 \\
166 \\
190 \\
\frac{-}{94} \\
113 \\
113 \\
115 \\
126 \\
155 \\
155 \\
\\
91 \\
97 \\
111\end{array}$ & $\begin{array}{l}1.0 \\
1.6 \\
1.9 \\
0.9 \\
1.1 \\
1.1 \\
1.1 \\
1.2 \\
1.5 \\
1.5 \\
\\
0.9 \\
1.0 \\
1.1\end{array}$ \\
\hline
\end{tabular}

Average of two specimens.

2 One specimen only.

3 Inspection sheets lost.

- Specimens have not progressed to this failure level after 200 months of exposure.

$\mathrm{T}$ Tab torn off.

failure, cannot be used as an early warning of impending failure. While early cracking of the coating on shingles may be startling to an uninformed observer, the data in tables 6 and 7 for smoothsurface specimens show the lack of correlation between early cracking and failure. Thus, cracking has not been used as one of the criteria of failure.

Cracking of coatings on shingles results from the large differences in thermal coefficient of linear expansion between the saturated felt and the shingle coatings. Data on these materials are difficult to obtain, but a few order-of-magnitude figures have been published. These are listed in table 8 .

It is evident from the above data asphalt moves roughly 25 times as much as the saturated felt does in the cross direction and 50 times as much as the saturated felt in the machine direction as the temperature changes. At the higher end of the range of temperatures encountered by roofing during exposure, the asphalt can accommodate the differential movements by flow, but at the lower end of the temperature range flow is not rapid enough and partial accommodation results by the curling of the shingle tabs. When this movement can no longer cope with the stresses, cracking occurs. These cracks usually run at right angles to the greatest differential movement: In the exposure of the smoothsurface specimens, all early cracking first occurred in the cross direction. These occurred very early in the exposure period, in some instances during the first winter, but the specimens continued to perform well for many years. There was no relationship between any of the levels of cracking and spalling. Therefore, nothing more will be said about cracking, for spalling has been set as the criterion for failure.

Returning to the performances of specific systems, it can be seen that many of the specimens containing blue black slate have not deteriorated to the 25 percent spalled level after 17 years of exposure. For these systems, just as with the asphalts without 
TABLE 7. Smooth surface spccimens ${ }^{1}$

$25 \mathrm{Mil}(0.64 \mathrm{~mm})$ Thickness

Outdoor Exposures

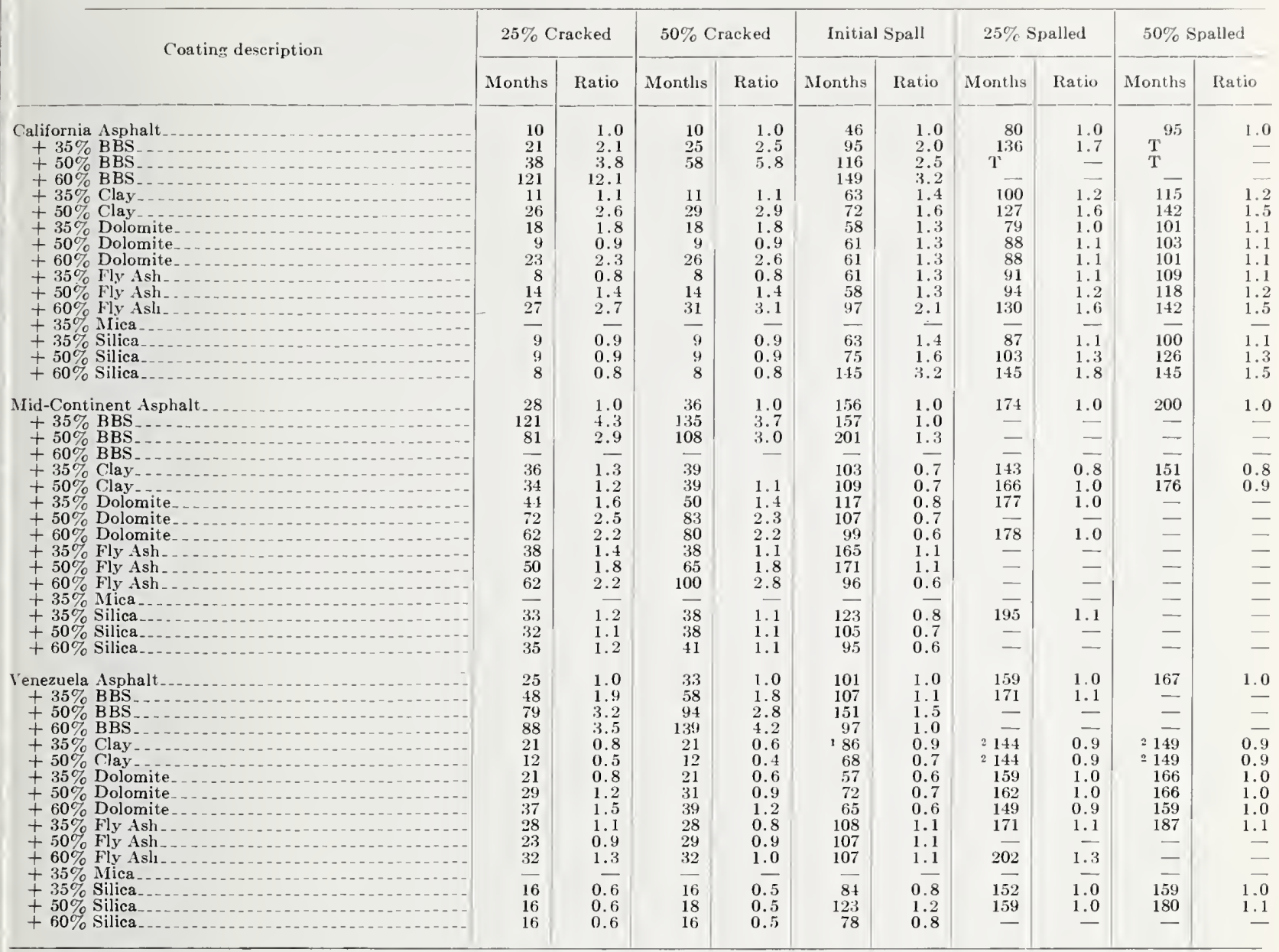

1 Average of two specimens.

2 One specimen only.

- Specimens have not progressed to this failure level after 200 montlis of exposure.

$\mathrm{T}$ Tab torn off.

additives, the thicker films are performing better and the asphalts are tending to fall in the same order of durability. It is also apparent, with one exception, that coatings with higher concentrations of blue black slate are deteriorating more slowly than those with lower concentrations.

For materials with other than those with platelike particle shapes, the response to mineral additives cannot be discussed in general terms [3]. The other additives used tended to have blocky to spherical shapes; their performances were varied in the three asphalts.

Fly ash was the next best performer in that it increased the durability of some coatings as much as 170 percent and in no instance were coatings containing fly ash less durable than the asphalt with which they were made. The higher concentrations again produced the best performers and the thicker films lasted longer than the corresponding thinner ones. Most of the Mid-Continent coatings with fly
TIRLE 8 .

\begin{tabular}{|c|c|c|c|}
\hline \multirow{2}{*}{ Material } & \multirow{2}{*}{$\begin{array}{l}\text { Coefficient of } \\
\text { linear expansion }\end{array}$} & Temperature & \multirow[t]{2}{*}{ Source } \\
\hline & & Range & \\
\hline $\begin{array}{l}\text { Asplaalt saturant } \\
\text { Asphalt coating }\end{array}$ & $\frac{6.1 \times 10^{-4}{ }^{\circ} \mathrm{C}^{-1}}{5.9 \times 10^{-4}}$ & $\begin{array}{r}{ }^{\circ} \mathrm{C} \\
15-60 \\
15-60\end{array}$ & $\begin{array}{l}(7) \\
(7)\end{array}$ \\
\hline $\begin{array}{l}\text { Petroleum asphalt } \\
\text { and fluxes }\end{array}$ & $6.3-6.8 \times 10^{-4}$ & $0-230$ & ${ }^{1}(7)$ \\
\hline $\begin{array}{l}\text { Asphalt- } \\
\text { various sources }\end{array}$ & $5.8-6.2 \times 10^{-4}$ & & (8) \\
\hline $\begin{array}{l}\text { Organic felt- } \\
\text { machine direction } \\
\text { Organic felt- }\end{array}$ & $1.1 \times 10^{-5}$ & $(-34)-(-1)$ & $1(9)$ \\
\hline $\begin{array}{l}\text { cross direction } \\
\text { Aluminum alloys }\end{array}$ & $\begin{array}{l}2.4 \times 10^{-5} \\
2.1-2.6 \times 10^{-5}\end{array}$ & $(-34)-(-1)$ & $\begin{array}{l}1(9) \\
1(10)\end{array}$ \\
\hline
\end{tabular}

1 Converted to metric system.

ash have not failed. The Venezuela coatings 25 mils thick with 50 and 60 percent fly ash are just beginning to fail, and the California-fly ash coatings have all failed in 1.1 to 1.5 times the durability of the 
California asphalt without additives. Thus, the pattern established by the unstabilized asphalts has been carried through to the coatings containing fly ash.

The effects of clay, dolomite, and silica on the durability of the smooth-surface specimens were more variable than those of blue black slate, fly ash, and mica. The silica was most beneficial in the California asphalt, for it increased its durability (25 percent coating spalled) as much as 80 percent. In all instances it increased the durability by at least 10 percent. Similarly, in the Mid-Continent asphalt it also increased the durability of the asphalt by at least 10 percent; the 25 -mil coatings with 50 and 60 percent silica have not failed after 200 months, or a 15 percent greater time than the straight asphalt specimens. The specimens made from the I'cnezuela asphalt-silica system again were in betwecn those with Mid-Continent and California asphalts, but the inprovement in durability by the silica was not as consistent as in the other trio asphalt systems. Three of the coatings performed only as well as the asphalt alone, one not quite as well, one a little better, and the one with 60 percent silica 25 mils thick is still performing well after 200 months.

In only a few combinations containing clay or dolomite were improvements in durability of more than 20 percent observed. Fifty percent clay increased the durability of the California asphalt in both thicknesses by 60 percent. Fifty percent dolomite improved the thin films of both Mid-Continent and Venezuela asphalt by 30 percent. Howcver, the other combinations performed within 20 percent of the durability of the straight asphalts.

Thus, in summary, the Mid-Continent asphalt was more durable than the Venezuela asphalt, which was more durable than the California asphalt. The mineral additives either improved the durability or had little effect. Mica and blue black slate always improved the durability of the three asphalts. Ily ash, silica, dolomite, and clay improved the durability to a lesser extent and only in specific combinations of composition and coatings thickness.

Figure 3 is a photograph of some of the specimens made with Mid-Continent asphalt after $161 / 2$ years of exposure. The test specimens are the five in each column under the identification tags, as identified in figure 3 .

The variation of performance with composition and coating thickness is evident in this photograph.

\subsection{Granule-Surfaced, Felt-Base Specimens}

Prior to cxposurc, samples of all of the granulesurfaced specimens were subjected to granule adhesion tests. The procedure used was ARIB Index No. $1.119[10]$, using the electrically operated equipment. As recommended in the procedure, the averagc weight loss for $102-\times 10$-in specimens when abraded dry must be in the range of 0.2 to $0.7 \mathrm{~g}$. The only composition that produced specimens that did not fall within this range was 60 percent blue black slate in Venezuela asphalt. A second set of specimens was made, but it also did not pass the test. Both sets of specimens were exposed and both experienced large losses of granules carly during their cxposure. The California specimens containing clay passcd the test marginally. They, also, lost some granules early during exposure. Howcver, none of thesc specimens has failed by the established criteria.

Figures 4 and 5 are photographs of California and Venezucla specimens after 15 years of exposure. The unstabilized asphalt coatings show noticeable losses of granules and cracking of the coatings. Cracking of the coatings is also evident in the California coatings containing clay. However, all of the granule-surfaced specimens are still performing well after 15 years and should give many more ycars of protection from the weather.

\section{Correlation With Exposures in Accelerated Weathering Machine}

Because most asphalt-prepared roofing is exposed as granule-surfaced material, the ultimate correlation must be between the granule-surfaced specimens exposed outdoors and the specimens exposed in the accelerated weathering test. Because none of the granule-surfaced specimens has failed by any of the established criteria for failure, a discussion of correlation would be meaningless. However, many of the smooth-surface, felt-base specimens have failed. While no quantitative correlation can be made until more specimens fail, certain parallels can be seen in figure 6 between the performances of these specimens and their corresponding aluminumbase specimens exposed in the weatherometer. The dots represent the average durability of four specimens on aluminum panels exposed in the weatherometers and the bars represent the average durability of two felt-base specimens exposed outdoors. Based on those specimens cxposed outdoors that have failed, it is quite apparent that many of the findings in the weatherometer test [3] can bc correlated with the exposures outdoors.

The California asphalt (Asphalt I in reference [3]) produced the least durable specimens. The Venezuela asphalt (Asphalt III in ref. [3] produced the next more durablc specimens, and the MidContinent asphalt (Asphalt II in ref. [4] ) the most durablc specimens. However, for some systems there was little or no difference in the durabilities of corresponding coatings made from the latter two asphalts.

For all three asphalts, mica (shown in tables 0 and 7 , but not in fig. 6) made the greatest improvement in performance. Blue-black slate was also beneficial to all threc asphalts. And dolomite, just as in the weatherometer tests, did not appreciably affect the durability of the three asphalts. On the other hand, clay, fly ash, and silica all arc performing 


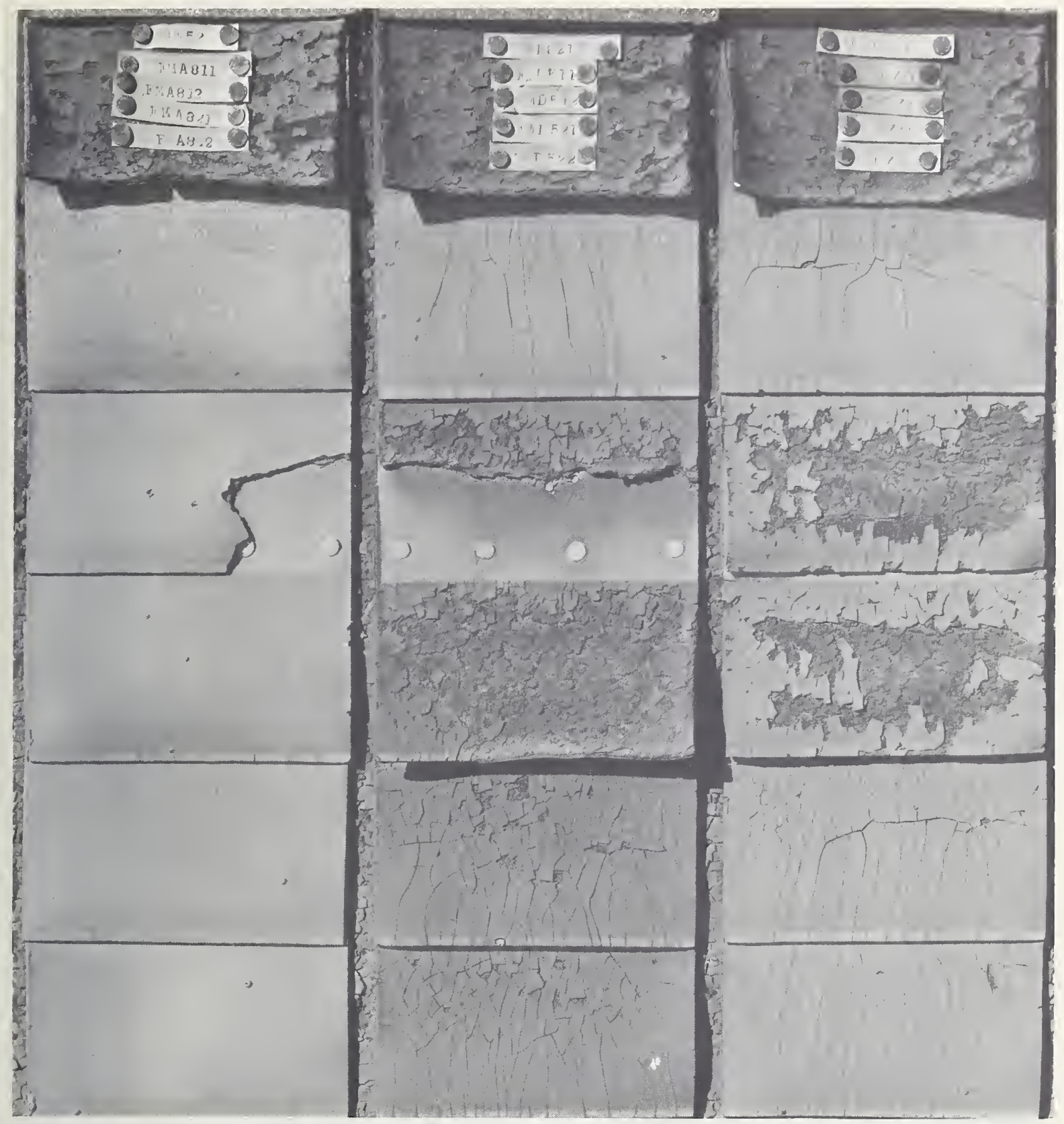

Figtre 3. Smooth-surface, felt-base specimens after $16 \frac{1}{2}$ years of cxposure 1

\begin{tabular}{|c|c|c|c|c|c|}
\hline \multicolumn{2}{|c|}{ Column 1} & \multicolumn{2}{|c|}{ Column 2} & \multicolumn{2}{|c|}{ Column 3} \\
\hline Coating composition & Thickness & Coating composition & Thickness & Coating composition & Thickness \\
\hline $35 \%$ Mica & $\underset{25}{\operatorname{mils}}$ & $60 \%$ Fly Ash & $\begin{array}{c}\text { mils } \\
25\end{array}$ & $60 \% \mathrm{Fly} \mathrm{Ash}$ & $\begin{array}{c}\text { mils } \\
25\end{array}$ \\
\hline $60 \%$ Blue Black Slate ${ }^{2}$ & 15 & $35 \%$ Fly Ash 2 & 15 & $50 \%$ Fly $\mathrm{Asl}$ & 15 \\
\hline $60 \%$ Blue Black Slate & 15 & $35 \% \mathrm{Fly} A \mathrm{sh}$ & 15 & $50 \%$ lily Ash & 15 \\
\hline $60 \%$ Blue Black Slate & 25 & $35 \%$ Fly Ash & 25 & $50 \%$ Fly Ash & 25 \\
\hline $60 \%$ Blue Black Slate & 25 & $35 \%$ Fly Ash & 25 & $50 \%$ Fly Ish & 25 \\
\hline
\end{tabular}

1 Mid-Continent Asphalt

2 Tabs partially torn off. 


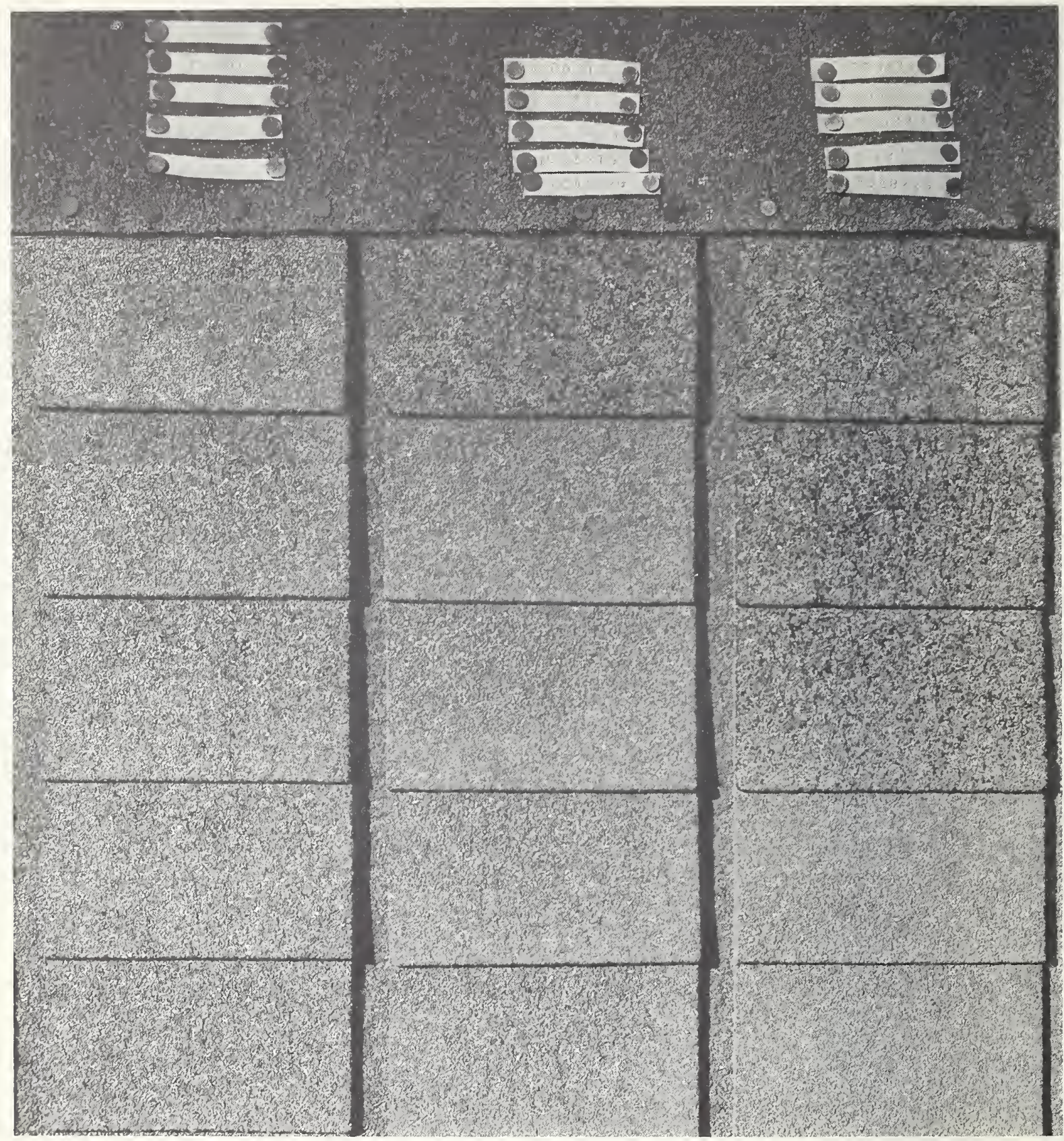

FIGIRE 4. Cranule-surfaced, felt-base Venezuela speeimens after 1i years of exposure

(Initial granule coverage approximately $25 \mathrm{lb} / 100 \mathrm{sq} \mathrm{ft}\left(1.22 \mathrm{~kg} / \mathrm{m}^{2}\right)$ )

\begin{tabular}{|c|c|c|c|c|c|}
\hline \multicolumn{2}{|c|}{ Column 1} & \multicolumn{2}{|c|}{ Column 2} & \multicolumn{2}{|c|}{ Column 3} \\
\hline Composition & $\begin{array}{l}\text { Coating } \\
\text { thickness }\end{array}$ & Composition & $\begin{array}{l}\text { Coating } \\
\text { thickness }\end{array}$ & Composition & $\begin{array}{l}\text { Coating } \\
\text { thickness }\end{array}$ \\
\hline & mils & & mils & & mils \\
\hline $60 \%$ Blue Black Slate & 25) & $50 \%$ Blue Black Slate & 25 & $35 \%$ Florida Clay & 25 \\
\hline $60 \%$ Blue Black Slate & 25 & $50 \%$ Blue Black Slate & 25 & $35 \%$ Florida Clay & 25 \\
\hline $35 \%$ Blue Black Slate & 25 & $35 \%$ Blue Black Slate & 25 & $60 \%$ Blue Black Slate & 25 \\
\hline $35 \%$ Blue Black Slate & 25 & $35 \%$ Blue Black Slate & 25 & $60 \%$ Blue Black Slate & 25 \\
\hline
\end{tabular}




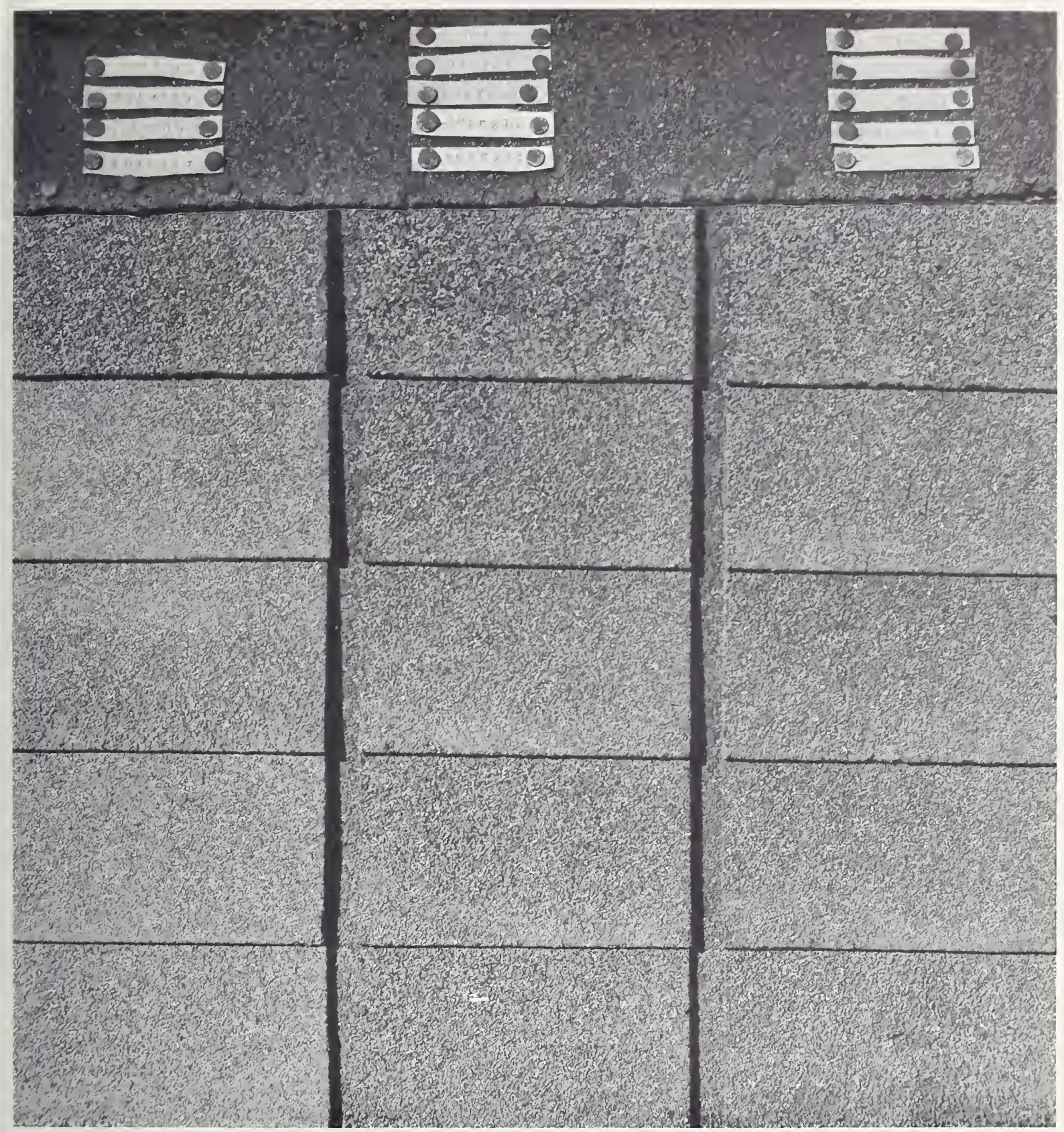

FIGIRE 5. Granule-surfaced, felt-base California specimens after 15 years of exposure

(Inítial granule coverage approxímately $25 \mathrm{lb} / 100 \mathrm{sq}\left[\mathrm{t}\left(1.22 \mathrm{~kg} / \mathrm{m}^{2}\right)\right.$ )

\begin{tabular}{|c|c|c|c|c|c|}
\hline \multicolumn{2}{|c|}{ Column 1} & \multicolumn{2}{|c|}{ Column 2} & \multicolumn{2}{|c|}{ Column 3} \\
\hline Composítion & $\begin{array}{l}\text { Coatíng } \\
\text { thickness }\end{array}$ & Composition & $\begin{array}{l}\text { Coating } \\
\text { thickness }\end{array}$ & Composition & $\begin{array}{l}\text { Coatíng } \\
\text { thickness }\end{array}$ \\
\hline & mils & & mils & & mils \\
\hline $60 \%$ Dolomite & 25 & $100 \%$ Asphalt & 25 & $100 \%$ Asphalt & 45 \\
\hline $50 \%$ Dolomite & 25 & $50 \%$ Blue Black Slate & 25 & $100 \%$ Asphalt & 45 \\
\hline $50 \%$ Dolomite & 25 & $50 \%$ Blue Black Slate & 25 & $100 \%$ Asphalt & 25 \\
\hline $35 \%$ Dolomite & 25 & $35 \%$ Blue Black Slate & 25 & $60 \%$ Blue Black Slate & 25 \\
\hline $35 \%$ Dolomite & 25 & $35 \%$ Blue Black Slate & 25 & $60 \%$ Blue Black Slate & 25 \\
\hline
\end{tabular}




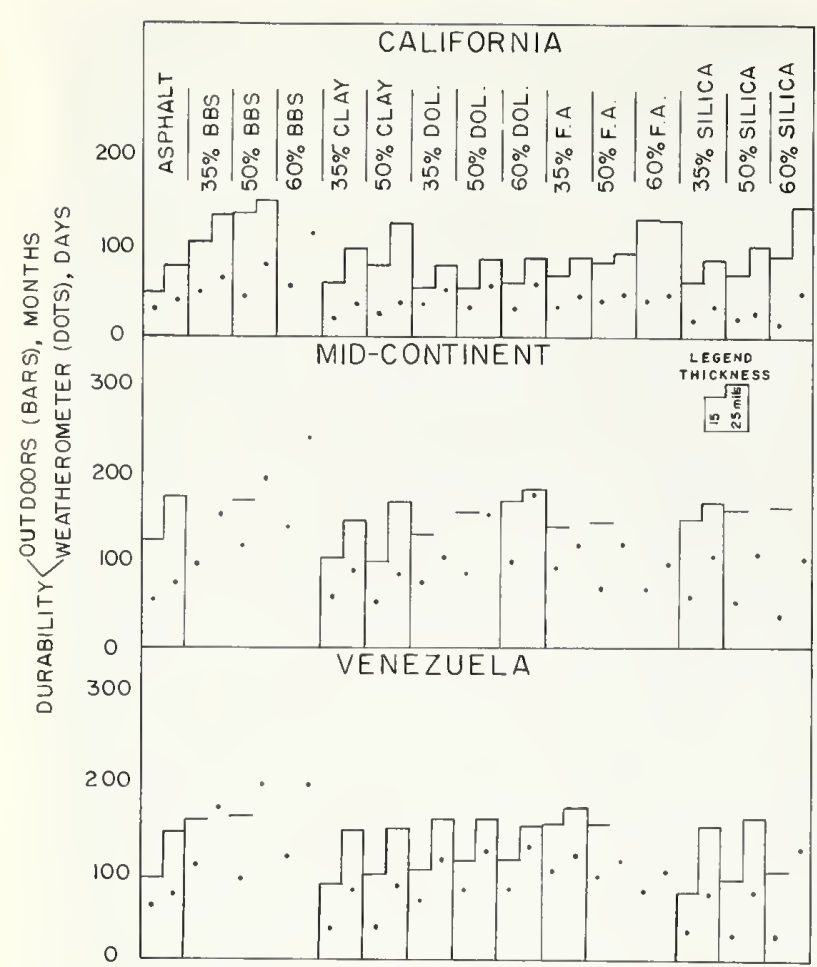

Fisure 6. Durability of smooth-surface specimens.

The outdoor exposures are represented by bars and the weatherometer exposures by dots. Where there are no tops on the bats, the specimens have not failed after 200 months of exposure. better than anticipated from the results of the weatherometer tests. Whereas, in a few of these systems in the weatherometers the coatings with additives were 20 percent less durable tlian their corresponding straight asphalt coatings, none exposed outdoors was less durable than its corresponding asphalt coating. In the extreme cases, such as 60 percent silica in the 15 mil coatings of all three asphalts, the specimens exposed outdoors were more durable than the corresponding straight asphalt specimens and the specimens in the weatherometers were roughly half as durable. Thus, where the results of the weatherometer tests have not corresponded with those obtained with the exposure outdoors, they have been on the conservative side.

The 25-mil thick coatings were more durable than the 15-mil coatings of the same mixes, but in many instances not 40 percent more durable. Both of these conditions were also apparent in the results of the weatherometer tests.

\section{Conclusions}

After 16 and a half years of exposure of smoothsurface and granule-surfaced roofing in Washington, D.C., the following conclusions can be drawn:

(1) All of the granule-surfaced specimens are performing satisfactorily. A few, which failed or were borderline in the granule-loss test, have lost noticeable quantities of granules during exposure.

(2) Of the smooth-surface specimens, those with 35 percent mica and 35,50 , and 60 percent blue black slate in all three asphalts have consistently outperformed the corresponding asphalt specimens without additives. The systems containing fly ash, dolomite, clay, and silica gave variable performances; each combination must be considered separately.

(3) The thicker coatings are outperforming the thinner coatings.

(4) There were differences in durability among the specimens made with the three asphalts, with the Mid-Continent asphalt being the most durable and the California the least. When mineral additives were mixed with the asphalts, corresponding differences in durability were observed.

(5) Based on the smooth-surface specimens, the results in the weatherometer tests in most instances predicted the relative durabilities of the coating. Where the weatherometers were different, the difference was in the conservative direction.

This work was sponsored by the Asphalt Roofing Manufacturers Association at the National Bureau of Standards. The author is grateful to the members of the Research Committee for their help in designing and monitoring this program and to William $\mathrm{H}$. Appleton, Robert F. Jackson, John Marchi, Shigeru Ishihara, John P. Falzone, Jefferson C. Weeks, Thomas R. Davis, Royce E. Stine, and Thomas Crowe for their help in perparing the exposure specimens and making the periodic inspections during $162 / 3$ years of exposure. The author wishes to express his gratitude, also, to the members of the staff of the National Bureau of Standards who helped make this work possible. 


\section{References}

11) Greenfeld, S. H., A method of preparing uniform films of bituminous materials, ASTM Bul. 193, 50 (1953). Adopted as ASTM Standard Method D 1669-62 and USA Standard A 1(09.40 - 1965.

[2] Greenfeld, S. H., Effects of thermal shock on the durability of asphalt coatings under accelerated test, ASTM Bul. 193, 46 (1953).

[3] Greenfeld, S. H., Effects of Mineral Additives on the Durability of Coating-Grade Roofing Asphalts, NBS Building Materials and Struct ures Report 147, (Sept. 1956).

[4] ASTM D 225-65, Asphalt Shingles Surfaced with Mineral Granules.
(5) Pfeiffer, J. I'., The Properties of Ashpaltic Bitumen, pp. 157-158 (Elsevier Publishing Co., New York, 195()$)$.

[6] Abraham, H., Asphalts and Allied Substances, 6th ed., 4. pp. 163-169, (1). Van Nostrand Co., New York, 1962).

17] Hoiberg, A., Bituminous Materials 1, 47 (Interscience Publishers, L'ew York, 1964).

[s] Cullen, W. C., Effect of thermal shrinkage on built-up roofing, NBS Monograph 89 (1965).

[9] Handbook of Physies and Chemistry, 42d erlition, 1528, (Chemical Rubber Publishing Co., 1960).

[10] Manual of Test Procedures for Roofing Granules, Asphalt Roofing Industry Bureau, (1956). 


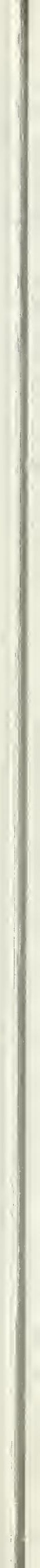




\section{Announcement of New Publications in Building Science Series}

Superintendent of Documents, Government Printing Office, Washington, D.C., 20402

Dear Sir:

Please add my name to the announcement list of new publications to be issued in the series: National Bureau of Standards Building Science Series.

Name

Company

Address

City State Zip Code

(Notification key N-339) 
The National Bureau of Standards ' was established by an act of Congress March 3, 1901. Today, in addition to serving as the Nation's central measurement laboratory, the Bureau is a principal focal point in the Federal Government for assuring maximum application of the physical and engineering sciences to the advancement of technology in industry and commerce. To this end the Bureau conducts research and provides central national services in four broad program areas. These are: (1) basic measurements and standards, (2) materials measurements and standards, (3) technological measurements and standards, and (4) transfer of technology.

The Bureau comprises the Institute for Basic Standards, the Institute for Materials Research, the Institute for Applied Technology, the Center for Radiation Research, the Center for Computer Sciences and Technology, and the Office for Information Programs.

THE INSTITUTE FOR BASIC STANDARDS provides the central basis within the United States of a complete and consistent system of physical measurement; coordinates that system with measurement systems of other nations; and furnishes essential services leading to accurate and uniform physical measurements throughout the Nation's scientific community, industry, and commerce. The Institute consists of an Office of Measurement Services and the following technical divisions:

Applied Mathematics-Electricity-Metrology-Mechanics-Heat-Atomic and Molecular Physics-Radio Physics - - Radio Engineering - Time and Frequency *-Astrophysics "-Cryogenics."

THE INSTITUTE FOR MATERIALS RESEARCH conducts materials research leading to improved methods of measurement standards, and data on the properties of well-characterized materials needed by industry, commerce, educational institutions, and Government; develops, produces, and distributes standard reference materials; relates the physical and chemical properties of materials to their behavior and their interaction with their environments; and provides advisory and research services to other Government agencies. The Institute consists of an Office of Standard Reference Materials and the following divisions:

Analytical Chemistry-Polymers-Metallurgy_Inorganic Materials-Physical Chemistry.

THE INSTITUTE FOR APPLIED TECHNOLOGY provides technical services to promote the use of available technology and to facilitate technological innovation in industry and Government; cooperates with public and private organizations in the development of technological standards, and test methodologies; and provides advisory and research services for Federal, state, and local government agencies. The Institute consists of the following technical divisions and offices:

Engineering Standards-Weights and Measures — Invention and Innovation - Vehicle Systems Research-Product Evaluation-Building Research-Instrument Shops-Measurement Engineering-Electronic Technology-Technical Analysis.

THE CENTER FOR RADIATION RESEARCH engages in research, measurement, and application of radiation to the solution of Bureau mission problems and the problems of other agencies and institutions. The Center consists of the following divisions:

Reactor Radiation-Linac Radiation-Nuclear Radiation-Applied Radiation.

THE CENTER FOR COMPUTER SCIENCES AND TECHNOLOGY conducts research and provides technical services designed to aid Government agencies in the selection, acquisition, and effective use of automatic data processing equipment; and serves as the principal focus for the development of Federal standards for automatic data processing equipment, techniques, and computer languages. The Center consists of the following offices and divisions:

Information Processing Standards-Computer Information - Computer Services - Systems Development-Information Processing Technology.

THE OFFICE FOR INFORMATION PROGRAMS promotes optimum dissemination and accessibility of scientific information generated within NBS and other agencies of the Federal government; promotes the development of the National Standard Reference Data System and a system of information analysis centers dealing with the broader aspects of the National Measurement System, and provides appropriate services to ensure that the NBS staff has optimum accessibility to the scientific information of the world. The Office consists of the following organizational units:

Office of Standard Reference Data-Clearinghouse for Federal Scientific and Technical Information "-Office of Technical Information and Publications-Library-Office of Public Information-Office of International Relations.

\footnotetext{
Headquarters and Laboratories at Gaithersburg, Maryland, unless otherwise noted; mailing address Washington, D.C. 20234.

Located at Boulder, Colorado 80302.

${ }^{3}$ Located at 5285 Port Royal Road, Springfield, Virginia 22151.
} 
U.S. DEPARTMENT OF COMMERCE WASHINGTON, D.C. 20230

OFFICIAL BUSINESS

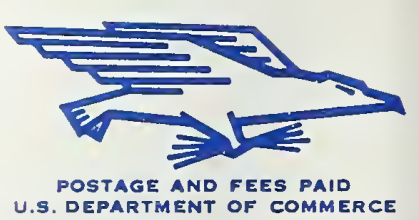

